
\title{
25 Research Soure \\ Urban-Rural Dimension of Fall and its Associated Risk Factors Amongst Community Dwelling Older Adult in Indonesia
}

\section{Susiana Nugraha ( $\square$ susiana.nugraha@gmail.com )}

Universitas Indonesia Faculty of Public Health: Universitas Indonesia Fakultas Kesehatan Masyarakat https://orcid.org/0000-0002-6723-742X

\section{Sabarinah Prasetyo}

Universitas Indonesia Faculty of Public Health: Universitas Indonesia Fakultas Kesehatan Masyarakat

Indri Hapsari Susilowati

Universitas Indonesia Faculty of Public Health: Universitas Indonesia Fakultas Kesehatan Masyarakat

Tribudi W Rahardjo

University of Respati Indonesia: Universitas Respati Indonesia

\section{Research Article}

Keywords: Fall, older adult, rural urban, risk factor

Posted Date: June 4th, 2021

DOI: https://doi.org/10.21203/rs.3.rs-542482/v1

License: (c) (i) This work is licensed under a Creative Commons Attribution 4.0 International License. Read Full License 


\section{Abstract}

Background: Falls are common problem among older people, WHO (2014) estimated 424,000 fatal cases of falls occur every year, making fall as the one of the causes of death in the older adult due to accidental injury. This study aimed to assess the risk of falling among community dwelling older adult in rural and urban area.

Method: Using a proportional sample size we determine 2 areas that describe rural and urban area in West Java Prefecture. The incidence of fall in the last 12 month is selected as outcome variable. Sociodemographic background, chronic medical condition, fear of falling, visual and hearing impairment, Activity Daily Living (ADL) Barthel index, the physical performance (Short Performance Physical Battery (SPPB)), and living environment were assessed to identify the factor contribute to the incidence of falling.

Result: a total of 611 older people participated this study consist of 381 (62\%)older persons living in rural area and 230 (38\%) person are living in urban area, 70 percent of them at the range of 60-69 years old, and $73 \%$ of them are female. The prevalence of fall in rural area (16.5\%), is significantly higher than urban area $(10.7 \%)$. The multiple logistic regression analysis showed, male gender $(\mathrm{OR}=0.29 ; 95 \% \mathrm{Cl}$ $(0.095-.882))$, chronic illness $(\mathrm{OR}=3.2595 \% \mathrm{Cl}(1.236-8.533)$ and visual impairment $(\mathrm{OR}=3.6 ; 95 \% \mathrm{Cl}$ $(1.517-8.544))$ are associated with risk of fall in among older adult living in urban area. On the other hand, Visual impairment $(\mathrm{OR}=1.81 ; 95 \% \mathrm{Cl}(1.027-3.179))$ and living environmental $(\mathrm{OR}=3.36 ; 95 \% \mathrm{Cl}$ (1.137-9.921)) are significantly associated with fall in among older adult living in rural area.

Conclusion: We identify the different risk factors for falls in urban and rural area. The results can be concluded that a different approach is needed to reduce the risk of falling for the older adult in urban and rural areas based on risk factors.

\section{Introduction}

Ageing process significantly influence the physical and functional capacity of the older adult that implicate weaknesses, limitations and disabilities. This condition can affect the balance that puts the older adult at high risk of falling. Fall-related injury in older adults has been recognized as a major public health issue. Older adult has decreased functional body motor as well as cognitive that increase the risk of falling. ${ }^{1-4}$

Falls are common problem among older people, it is estimated 424,000 fatal cases of falls occur every year, ${ }^{5}$ this situation enacting fall as the one of the causes of mortality in the older adult due to accidental injury. More than $80 \%$ of fall related deaths in low- and middle-income countries, accounting for more than two-thirds of the highest deaths among adults over the age of $60 .{ }^{5}$ The Indonesian national health survey (2018) reported that the proportion of injuries caused by falls among the age group of 55 years or more is $25 \%$, and $67 \%$ of falls occur in the home environment. ${ }^{6}$ 
In 2019, the percentage of older people population reached 9.60 percent or around 25.64 million people. ${ }^{7}$ This condition shows that Indonesia is transitioning towards aging population because the percentage of the population aged over 60 years reaches above 7 percent of the total population and will become a country with an aging population structure if it is accounted more than 10 percent. Considering such a large population of older people, it is very important to explore factors that may cause accidental falls that deteriorate older people's health. Various effects of falls that can occur in the older adult, including post-fall anxiety syndrome, injury to either soft tissue or broken bones, hospital treatment, disability (decreased mobility), decreased functional status / decreased independency, increased use of health care facilities, and can even result in mortality. ${ }^{8-11}$ The adverse effect of fall might significantly influence older adult mobility, hence fall experience will be a risk of decreased quality of life up to $70 \%$. ${ }^{12}$

Fall risk for community-dwelling older people differs somewhat from assessment in a hospital or longterm care facilities setting. Older people living in community are usually more active, and more physically independent than those living in long term care facilities. Nevertheless, fall assessment needs to be multifactorial, because of the complex nature of falls. Multiple factors have been shown to increase fall risk in community-dwelling adults over the age of 65 , these factors can be divided into 3 categories including: 1) Demographic factors (Age, gender), Intrinsic factors include health condition that can be defined as the existence of chronic illness ${ }^{13,14}$, history of falling. ${ }^{15-17}$ functional capacity indicate by the level of dependency in performing activity daily living and Physical capacity as indicate by gait speed and balance examination, ${ }^{18,1920-22}$ sensory impairment such as visual impairment and hearing impairment, ${ }^{23-25}$ and depression. $3,8,9,26$ Furthermore, another risk factor for falling that come from outside the older adult also been identified as the extrinsic risk factor for falling such as living environment, home hazard and neighborhood accessibility 21,27 and medication consumed by the older adult. ${ }^{28,29}$

Given the large longstanding disparities in rural and urban areas, investigating the rural-urban dimension of fall among Indonesian older population is a major concern of this study. The difference between rural and urban living environment will have implications for the types of fall risk faced by the elderly. The division of rural and urban areas is differentiated based on certain criteria that meet administrative requirements in terms of population density, percentage of agricultural households and the presence or access of urban facilities such as roads, formal education facilities, public health facilities, etc. ${ }^{30}$ Indonesian older population is spread both in urban and rural areas, where the elderly who live in urban areas are higher than in rural areas (52.80 percent compared to 47.20 percent). ${ }^{7}$ The living environments for rural and urban older people are also dissimilar. For example, most rural residents live in wider onestory houses whereas urban residents live in densely populated housing environments and tend to have houses that are more than one story high. Access to public services is easier for urban communities to reach good transportation facilities, while rural communities tend to require heavier efforts such as walking through areas with hilly topography. Significantly diverse environmental factors could be a reason for dissimilar fall incidence rates among elders residing in rural and urban area. The cultural tradition, leisure and physical activities among rural and urban older population are also dissimilar. 
Taking into account the rural and urban differences presented in the previous literature, this study hypothesizes that the rural-urban disparities discussed above may result in varying patterns and determinants of fall between rural and urban older people.

Although numerous studies have identified factors of falling, few studies have focused on examining the rural and urban dimension for the risk of fall among Indonesian older people. Additionally, no study has contrasted incidence and risk factor of falls among urban and rural older people in Indonesia. To address the above concerns, this study analyzes community-dwelling individuals aged 60 and over to reveal the incidence of falls among older people in urban and rural and to reveal the contrast environmental and personal risk factors for falls among rural and urban Indonesian older people. The study contributes to the literature by improving our understanding on risk factors of falls among Indonesian rural and urban elders. A clearer understanding of how personal characteristics, health condition, behavioural and lifestyle factors influence fall rates in Indonesian populations is essential for elucidating fall prevention strategies. Findings from Indonesian study also provide useful implications for other countries with similar characteristics.

\section{Method}

\section{Study design}

This is a descriptive analytic study that using cross sectional approach. Household survey was conducted during June - September 2020. West Java Provinces selected as one of Indonesian province that entering aging population (have more than $10 \%$ older people population). ${ }^{31}$

\section{Population and sample}

Population of this study are community dwelling older adult aged 60 years old or more. The sample size calculation is based the prevalence of fall in community dwelling older adult in Indonesia by using fall prevalence $29 \%$ in the previous year ${ }^{32}$ and precision was considered as $95 \%( \pm 0.05)$ counted for urban area and each area. A cluster sampling method was used to achieve the required study sample from 2 selected area out of 28 municipalities in West Java administrative area namely Bandung Regency that representing rural area and Bandung City representing urban area. From those selected municipalities, then we randomly selected 4 sub-district from each rural and urban area. From each subdistrict we randomly selected 2 villages for each subdistrict in rural area and 2 urban villages in urban area, a total of 16 urban village and village are selected. The sample size for each village was calculated proportionally and the sampling was carried out randomly in each village.

\section{Variable and Measures}

Outcome variable 
Fall is become outcome on this study. Fall is assessed with following questions; "Have you fallen down in the last twelve months?" and "How many time have you fallen down?"

\section{Risk Factor for Fall}

Sociodemographic factor included age, sex, education, occupation status and residential area. Chronic medical conditions were assessed with the question "Has a doctor/paramedic/nurse/midwife ever told you that you had following diseases?" ("hypertension, diabetes or high blood sugar, heart diseases, stroke, arthritis/rheumatism, and depression") (Yes, No). The existence of one or more chronic medical condition considering as having chronic illness.

Visual impairment refers to any degree of impairment to a person's ability to see that affects his or her daily life ${ }^{33}$. Visual impairment was assessed subjectively with the questions "Do you have any problem with your vision? Such as blurred vision? (Yes/No) any answer will be confirmed with tumbling $\mathrm{E}$ chart test to confirm subjective visual impairment. Any correction with glasses will be considered as normal visual.

Hearing impairment refer to a person who is not able to hear as well as someone with normal hearing hearing thresholds of $20 \mathrm{~dB}$ or better in both ears ${ }^{34}$. This study assessed the subjective hearing impairment using the question: "Do you have any problem with your hearing function?" (Yes/No. Any subjective answer, to be confirmed by observation and whisper test. Any correction with hearing aids considered as normal hearing.

Functional capacity was measured by Barthel index of ADL (Activity Daily Living). This Barthel index measures the likelihood of being able to live at home with a degree of independence ${ }^{35}$. Ten basic activities of daily living (ADL) are captured: bowels, bladder, grooming, toilet use, feeding, transfers, walking, dressing, climbing stairs, and bathing. A dichotomous category selected as mild/severe dependent (score $\leq 19$ ) and independent (score 20) ${ }^{35}$.

The physical performance measured by SPPB (Short Physical Performance Battery). SPPB is a wellknown and sensitive performance test which combines the results of 3 balance tests, a gait speed test and a chair stand test into one score $\mathrm{e}^{36,37}$. Hand-clocked durations are used to indicate the performance capacity for individual components which are scaled to a grade between 0 and 4 and add up to a score between 0 and 12). This performance is dichotomized in to poor and good physical performance.

Living environmental risk factor was assessed with the CDC Home Fall Prevention Checklist for Older Adults to identify home hazard that may increase the risk of falling, including room lighting, floor condition, stairs and steps, kitchen, bedroom and safety in the bathroom. Any "Yes" in one of the hazards categorized as unsafe environment. Medication

Data analysis 
Data analysed using statistical software IBM SPSS statistics 22. A descriptive analytic was perform to describe the sociodemographic profile of study participants. Independent sample t-test and chi-square analysis selected to compare risk of falling among the older person living in rural and urban area. Binary multiple logistic regression analysis performed to identify the association between fall and the risk factor.

Prior to participation, all older people participated in this study voluntarily signed their informed consent to prove their voluntary contribution on this study. This study has passed the ethical clearance from institutional research bureau of Universitas Indonesia with approval number: Ket326/UN2.F10.D11/PPM.00.02/2020.

\section{Results}

This study conducted in two representative rural and urban area in West Java, Indonesia. A total of 611 sample are satisfy the statistical analysis, older adult participated in this study consisting 230 older adult from urban area and 381 older adult from rural area with $77 \%$ response rate.

Table 1 showed that $19 \%$ of the older adult are having history fall in the last 12 month, and there is no significant difference between those living in rural and urban area. Older adult living in rural area are significantly older than those living in urban area. Older adult living in rural area are having higher proportion of hearing impairment and visual impairment. Rheumathoid/osteoarthritis reported by $59 \%$ of study participants, most of study participants are having unsafe living environment. Older adult living in rural area having significantly higher number of unsafe living environment compare to urban area. Older adult living in rural area are significantly have poorer functional capacity and physical performance. There is no significant different in the frequency of fall between urban and rural setting.

Table 3 describe the result from logistic regression analysis for the variables associated with fall in older adult living in rural and urban area. Gender is significantly associated with fall in among older adult living in urban area. Being male likely to become protective factor for fall OR=.289; $95 \% \mathrm{Cl}(0.095-0.882)$. Visual impairment is significantly associated with the incidence of fall both in rural and urban area whereas older people living in urban area who have visual impairment likely to have 3 times higher risk to fall $O R=3.601 ; 95 \% \mathrm{Cl}(1.517-8.544)$. On the other hand, older people living in rural area who have visual impairment likely to fall 1,8 times higher compare to normal visual $(\mathrm{OR}=1.807 ; 95 \% \mathrm{Cl}(1.027-3.179)$.) Chronic medical condition is only associated with the incidence of fall in elderly living in urban area, older people who have chronic medical condition likely to fall 3 times higher compare to healthy older people $\mathrm{OR}=3.247 ; 95 \% \mathrm{Cl}(1.236-8.533)$. Living environment is associated with the incidence of fall in older people living in rural area, those who have unsafe environment likely to fall three times higher than those with safe environment OR=3.358 (1.137 - 9.921).

\section{Discussion}


This study sought to identify the difference risk factor of fall among community dwelling older adult in urban and rural area using multifactorial approach. We identified significant different in the risk factor model in urban and rural setting. The findings suggest that more falls occurred among older people living in rural than urban area; and the fall incidence rate is higher among females than males. Being male, having visual impairment and the existence of chronic illness are significantly associated with the incidence of fall in among older people living in urban area. Meanwhile, for the older people living in rural areas, we identified visual impairment and safety of the living environment as risk factors for falls.

Gender has been identified as on of risk factor for fall among older people living in urban area. Female older people likely to have higher risk of fall compare to male. This finding is inline with study conducted by Zhang et.al (2019) in among Chinese, that male older people living in urban area are likely to have lesser fall than female. ${ }^{38}$ This finding can be assumed that male older people in urban areas are mostly former workers who work outside the home, which allows them to have better muscular endurance than women who are mostly housewives. The remaining muscle strength allows it to be a protective factor for falls. ${ }^{39}$

Chronic illness is experienced by majority of the older adult both living in urban and rural area. Chronic illness can be defined as degenerative diseases that experienced by the older adult as part of their ageing consequence. Although the prevalence of chronic illness in older adult living in rural area are significantly higher than those living in urban area, the direct association between chronic illness and fall was only found in urban model. As being widely known that chronic illness has a significant effect on the physical and functional capacity of the older adult. Chronic illness may have significant impact on the balance and posture stability of the older adult which will increase the risk of falling. ${ }^{40}$ Several studies conducted by former researcher identified the association between chronic illness and the incidence of fall in older adults. $16,41,42$ Compare to the older adult living in rural area, older adult living in urban area with chronic illness are likely to fall 3 times higher.

This study identify visual impairment is significantly associated with the incidence of falling in older adult living in rural and urban area. Visual impairment refers to the condition that a person have subjective complain on their vision acuity that affecting daily activities. This finding is in line with former study conducted by Hong at. Al (2014) on their longitudinal study among older people with visual impairment, who identified that older people who have visual impairment likely to have two or more fall. 43 Older adult with visual impairment and high mobility are at higher risk of falling. Previous studies have identified the effect of visual impairment on falls. Another study conducted on the Shinpey Eye Study community in China showed that, the incidence of falling was significantly associated with the visual acuity of Snellen which was best corrected for less than 6/12. Furthermore, a study in Shenzen China showed that impaired visual increased the risk of falling with $\mathrm{RR}=1.46,95 \% \mathrm{Cl} 1.03$ to $2.08 .{ }^{4}$

This study also finds that unsafe living environment likely to increase 3 times higher risk of falling in among older people in rural area. Unsafe living environment refer to the condition of living environment that considered as unsafe for older people to perform their daily activities. Approximately $96 \%$ of older 
adult living in rural area living in unsafe home environment and may increase the risk of falling. There are fundamental differences in the environmental conditions of the elderly in rural and urban areas. Older adult living in urban areas are more likely to occupy modern housing with bathrooms and toilets in the house. Meanwhile, in rural areas, traditionally use shared communal latrines that placed outside their home. Therefore, older people in rural area have to leave the house to access toilets and clean water. The topography of rural areas, which is generally hilly and rocky, increases the risk of imbalance which has implications for falls. This study is in agreement with former study conducted by Zhang et.al (2014) identified the significant association between living environment and the incidence of fall in among older people in rural area. ${ }^{38}$

\section{Conclusion}

The main part of this research has concerned whether factors associated with senior falls are different between rural and urban residents. This study identifies different risk factors for falling among older people based on the characteristics of the area of residence. These findings have implications for the importance of different approaches to fall prevention efforts of older people in urban and rural areas. Implications drawn from this research provide suggestions for the government and local agencies to develop suitable fall prevention strategies using rural and urban approach especially concerning in gender, visual impairment, having existing chronic illness, and living environment.

Study limitation

This limitation confounds the ability to consider covariates effecting outcomes. First, the data are based on a cross-sectional survey. As other cross-sectional studies, there is an inherent weakness of not being able to separate the cause-effect relationships of variables. In addition, recall bias may exist, especially among those elders who have poor memory. Since the data were obtained on the basis of 12 month fall recall and only the most recent fall was queried in detail, it is possible that the frequency of falls was underreported. The measures of environmental factors are also scarce it is based on observation during data collection, the older people behaviour toward living environment were not being assessed. Further study needs to exploring fall risk factors in a more comprehensive manner. Even with the limitations, this study is one of the first ones study that analyse rural-urban dimension using representative sample size that risk factors of falls among Chinese Indonesian community-dwelling elders in both rural and urban areas. Findings of this research offer an important base for conducting future prospective studies and launching possible fall prevention program for older people.

\section{List Of Abbreviations}

OR: odds ratios

$\mathrm{Cl}$ : confidence intervals 


\section{Declarations}

Ethics approval and consent to participate

The study protocol was approved by the ethics committees of the institutional research bureau of Universitas Indonesia with approval number: Ket-326/UN2.F10.D11/PPM.00.02/2020 and has been conducted in accordance with the Ethical Guidelines for Medical and Health Research Involving Human Subjects by the Indonesian Government.

Consent for publication

Not applicable.

Availability of data and materials

The datasets generated and analysed during the current study are not publicly available because the Ethical Guidelines prohibit researchers from providing their research data to other third-party individuals.

Competing interest

The authors declare that they have no competing interest with respect to this research study and paper.

Funding

This work was supported by the directorate of research and development University of Indonesia under PUTI Doktor scheme 2020. The sponsor was not involved in study design, data collection, analysis and interpretation of data; in the writing of the report; or in the decision to submit the article for publication.

Authors' contributions

SN was responsible for the design and conduct of the study, the collection, analysis, and interpretation of data, and the writing of the article. SP, HIS and TR and SP contributed to the data interpretation and discussion of the implications of this work. All authors read and approved the final manuscript.

\section{References}

1. Deniro AJN, Sulistiawati NN, Widajanti N. Hubungan antara Usia dan Aktivitas Sehari-Hari dengan Risiko Jatuh Pasien Instalasi Rawat Jalan Geriatri The Relationship between Age and Activity of Daily Living with. 2017;4(4):199-203.

2. Fuller G. Falls in the elderly. In: American Family Physician. Leawood, KS: American Academy of Family Physicians.; 2000. p. 2159-68.

3. Kvelde T, Lord SR, Close JCT, Reppermund S, Kochan NA, Sachdev P, et al. Depressive symptoms increase fall risk in older people, independent of antidepressant use, and reduced executive and physical functioning. Archives of Gerontology and Geriatrics. 2015 Jan;60(1):190-5. 
4. Zhou H, Peng K, Tiedemann A, Ji P, Sherrington C. Risk factors for falls among older community dwellers in Shenzhen, China. Injury Prevention [Internet]. 2019 Feb;25(1):31. Available from: https://search.proquest.com/docview/2171128205?accountid=17242

5. WHO WHO. Global Report on Falls Prevention in Older Age. Geneva; 2014.

6. Ministry of Health Republic Indonesia. Riskesdas 2018 (National Basic Health Reserach 2018). Riset Kesehatan Dasar. Jakarta; 2018.

7. National Statistic Agency. Statistik Penduduk Lanjut Usia 2019 (Statistic of Elderly Citizen, 2019) [Internet]. Statistik Penduduk Lanjut Usia di Indonesia 2019. Jakarta; 2019. Available from: https://sirusa.bps.go.id/sirusa/index.php/dasar/view?kd=3581\&th=2019

8. Iaboni A, Flint AJ. The complex interplay of depression and falls in older adults: a clinical review. The American journal of geriatric psychiatry: official journal of the American Association for Geriatric Psychiatry. 2013 May;21(5):484-92.

9. Stewart Williams J, Kowal P, Hestekin H, O'Driscoll T, Peltzer K, Yawson A, et al. Prevalence, risk factors and disability associated with fall-related injury in older adults in low- and middleincomecountries: results from the WHO Study on global AGEing and adult health (SAGE). BMC Medicine. 2015 Dec;13(1):147.

10. Hoffman GJ, Hays RD, Shapiro MF, Wallace SP, Ettner SL. The Costs of Fall-Related Injuries among Older Adults: Annual Per-Faller, Service Component, and Patient Out-of-Pocket Costs. Health Services Research. 2017 Oct;52(5):1794-816.

11. Delbaere K, Crombez G, Vanderstraeten G, Willems T, Cambier D. Fear-related avoidance of activities, falls and physical frailty. A prospective community-based cohort study. Age and Ageing. 2004;

12. Yoshida S. A Global Report on Falls Prevention Epidemiology of Falls. WHO report. Geneve; 2012.

13. Salive ME. Multimorbidity in older adults. Epidemiologic Reviews. 2013;35(1):75-83.

14. Hirase T, Inokushi S, Matsusaka N, Nakahara K, Okita M. A modified fall risk assesement tool that is specific to physical function predict fall in community dwelling edlerly people. NAOSITE, Nagasaki University Academic Output Site. 2014;37(4):159-65.

15. Wongsawat S. Predicting Factors for Quality of Life of Elderly in the Rural Area. International Journal of Art \& Sciences. 2017;09(04):363-71.

16. Bao W, Hu D, Shi X, Sun L, Zhu X, Yuan H, et al. Comorbidity increased the risk of falls in chinese older adults: A cross-sectional study. International Journal of Clinical and Experimental Medicine. 2017;10(7):10753-63.

17. Hsiao-Ting C, Hsi-Chung C, Chou P. Factors Associated with Fear of Falling among CommunityDwelling Older Adults in the Shih-Pai Study in Taiwan. PLoS One. 2016 Mar;11(3).

18. Ibrahim A, Singh DKA, Shahar S, Omar MA. Timed up and go test combined with self-rated multifactorial questionnaire on falls risk and sociodemographic factors predicts falls among community-dwelling older adults better than the timed up and go test on its own. Journal of Multidisciplinary Healthcare. 2017;10:409-16. 
19. Palumbo P, Palmerini L, Bandinelli S, Chiari L. Fall risk assessment tools for elderly living in the community: Can we do better? PLoS ONE. 2015;10(12):1-13.

20. Renfro Oxman M. Multifactorial screening for fall risk in community-dwelling older adults in the primary care office: Development and validation of the Fall Risk Assessment \& Screening Tool (FRAST). Dissertation Abstracts International: Section B: The Sciences and Engineering. The University of Montana Missoula; 2011.

21. Thiamwong L, Thamarpirat J, Maneesriwongul W, Jitapunkul S. Thai falls risk assessment test (Thai-FRAT) developed for community-dwelling thai elderly. Journal of the Medical Association of Thailand. 2008;91(12):1823-32.

22. Martins AC, Moreira J, Silva C, Silva J, Tonelo C, Baltazar D, et al. Multifactorial screening tool for determining fall risk in community-dwelling adults aged 50 years or over (FallSensing): Protocol for a prospective study. Journal of Medical Internet Research. 2018 Aug;20(8).

23. Gopinath B, Mcmahon CM, Burlutsky G, Mitchell P. Hearing and vision impairment and the 5-Year incidence of falls in older adults. Age and Ageing. 2016;45(3):353-8.

24. Mei O Y, El Fakiri F. Gender Differences in Risk Factors for Single and Recurrent Falls Among the Community-Dwelling Elderly. SAGE Open. 2015;5(3).

25. Tideiksaar T, Generation R. Sensory Impairment and Fall Risk. Questia Journal. 2003;26(4):22-7.

26. Nugraha S, Susilowati IH, Prasetyo S, Pengpid S, Peltzer K. Sociodemographic Characteristics and Depression as Risk Factors for Falls among Indonesian Elderly. Thai Journal of Public Health. 2020;50(1):25-36.

27. Curl A, Thompson CW, Alves S, Aspinall P. Outdoor Environmental Supportiveness and Older People's Quality of Life: A Personal Projects Approach. Journal of Housing For the Elderly. 2016 Jan;30(1):117.

28. Hatahira H, Hasegawa S, Sasaoka S, Kato Y, Abe J, Motooka Y, et al. Analysis of fall-related adverse events among older adults using the Japanese Adverse Drug Event Report (JADER) database. Journal of Pharmaceutical Health Care and Sciences. 2018;4.

29. Dhalwani NN, Fahami R, Sathanapally H, Seidu S, Davies MJ, Khunti K. Association between polypharmacy and falls in older adults: a longitudinal study from England. BMJ Open. 2017 Oct;7(10):e016358.

30. BPS (National Statistic Bureau). Klasifikasi Perkotaan dan Perdesaan di Indonesia (Rural and Urban Classification in Indonesia). Indonesia; 2010.

31. National Statistic Agency. Statistik Penduduk Lanjut Usia S (Badan Pusat Statistik)-National S2019 (Statistic of Elderly 2019). Jakarta; 2019.

32. Susilowati IH, Nugraha S, Sabarinah S, Peltzer K, Pengpid S, Hasiholan BP. Prevalence and risk factors associated with falls among community-dwelling and institutionalized older adults in indonesia. Malaysian Family Physician. 2020;15(1):30-8.

33. Sapp W. Visual Impairment. In: Peterson Penelope, Baker Eva MB, editor. International Encyclopedia of Education (Third Edition), 2010. Leawood, KS: Elsevier Inc.; 2010. p. 880-5. 
34. World Health Organization. Hearing loss in persons 65 years and older based on WHO global estimates on prevalence of hearing loss. WHO report [Internet]. 2012;1-14. Available from: https://www.who.int/pbd/deafness/news/GE_65years.pdf

35. Saisana M. Barthel Index. In: Michalos AC, editor. Encyclopedia of Quality of Life and Well-Being Research [Internet]. Dordrecht: Springer Netherlands; 2014. p. 325-6. Available from: https://doi.org/10.1007/978-94-007-0753-5_147

36. Treacy D, Hassett L. The Short Physical Performance Battery. Journal of Physiotherapy [Internet]. 2018;64(1):61. Available from: http://dx.doi.org/10.1016/j.jphys.2017.04.002

37. Guralnik, Ferrucci, Simonsick, Salive, Wallace. Short physical performance battery protocol and score sheet. Stand. 1994;1-8.

38. Zhang L, Ding Z, Qiu L, Li A. Falls and risk factors of falls for urban and rural community-dwelling older adults in China. BMC Geriatrics. 2019;19(1):1-17.

39. Lindle RS, Metter EJ, Lynch NA, Fleg JL, Fozard JL, Tobin J, et al. Age and gender comparisons of muscle strength in 654 women and men aged 20-93 yr. Journal of Applied Physiology. 1997;83(5):1581-7.

40. Salzman B. Gait and balance disorders in older adults. American Family Physician. 2011;82(1):61-8.

41. Sibley KM, Voth J, Munce SE, Straus SE, Jaglal SB. Chronic disease and falls in community-dwelling Canadians over 65 years old: A population-based study exploring associations with number and pattern of chronic conditions. BMC Geriatrics. 2014;14(1):1-11.

42. Nugraha S, Susilowati IH, Sabarinah, Pengpid Pletzer, Karl S. Multimorbidity Increases the Risk of Falling Among Indonesian Elderly Living in Community Dwelling and Elderly Home: A Cross Sectional Study. Indian Journal of Public Health Research and Development. 2019;10(11):2263-7.

43. Hong T, Mitchell P, Burlutsky G, Samarawickrama C, Wang JJ. Visual impairment and the incidence of falls and fractures among older people: Longitudinal findings from the blue mountains eye study. Investigative Ophthalmology and Visual Science. 2014;55(11):7589-93.

\section{Tables}

\section{Table 1 Characteristic of study participants}




\begin{tabular}{|c|c|c|c|c|}
\hline Variables & Urban $(n=230)$ & Rural ( $n=381)$ & \multicolumn{2}{|c|}{$P$ value } \\
\hline \multicolumn{5}{|l|}{ Ages } \\
\hline 60-69 Years old & $156(67.8 \%)$ & $271(71.1 \%)$ & $427(69.9)$ & 0.001 \\
\hline 70-79 years old & $68(29.6 \%)$ & $72(18.9 \%)$ & $140(22.9 \%)$ & \\
\hline 80 years old or more & $6(2.6 \%)$ & $38(10 \%)$ & $44(7.2 \%)$ & \\
\hline \multicolumn{5}{|l|}{ Gender } \\
\hline Male & $51(22.2 \%)$ & $113(29.7 \%)$ & $164(26.80 \%)$ & 0.756 \\
\hline Female & $179(77.8 \%)$ & $268(70.3 \%)$ & $447(73.20 \%)$ & \\
\hline \multicolumn{5}{|l|}{ Current Occupation } \\
\hline Actively working & $32(13.9)$ & $172(45.1 \%)$ & $204(33.4 \%)$ & 0.001 \\
\hline Not Working & $198(86.1 \%)$ & $209(54.9)$ & $407(66.6)$ & \\
\hline \multicolumn{5}{|l|}{ Visual Impairment } \\
\hline No & $175(76.1 \%)$ & $157(41.2 \%)$ & $332(54.3 \%)$ & 0.001 \\
\hline Yes & $55(23.9 \%)$ & $224(58.8 \%)$ & $279(45.7 \%)$ & \\
\hline \multicolumn{5}{|l|}{ Hearing Impairment } \\
\hline No & $185(30.3 \%)$ & $302(49,4 \%)$ & $487(79.7 \%)$ & 0.001 \\
\hline Yes & $25(4.1 \%)$ & $99(16.2 \%)$ & $124(20.3 \%)$ & \\
\hline \multicolumn{5}{|l|}{ Chronic medical condt. } \\
\hline Hypertension & $89(38.7 \%)$ & $174(45.7 \%)$ & $263(43 \%)$ & 0.124 \\
\hline Stroke & $8(3.5 \%)$ & $9(2.4 \%)$ & $17(2.7 \%)$ & 0.236 \\
\hline Heart Diseases & $16(7.0 \%)$ & $12(3.1 \%)$ & $28(4.5 \%)$ & 0.028 \\
\hline Diabetes & $30(13 \%)$ & $23(6 \%)$ & $53(8.6 \%)$ & 0.003 \\
\hline Rheumatoid/osteoarthritis & $112(48.7 \%)$ & $250(65.6 \%)$ & $362(59 \%)$ & 0.001 \\
\hline Parkinson & $3(1.3 \%)$ & $27(7.1 \%)$ & $30(4.9 \%)$ & 0.003 \\
\hline \multicolumn{5}{|l|}{$\begin{array}{l}\text { Having unsafe home } \\
\text { environment }\end{array}$} \\
\hline No & $24(10.4 \%)$ & $12(3.1 \%)$ & $36(5.90 \%)$ & 0.001 \\
\hline Yes & $206(89.6 \%)$ & 369 (96.9\%) & $575(94.10 \%)$ & \\
\hline
\end{tabular}




\begin{tabular}{|lllll|}
\hline Independence & $199(86.5 \%)$ & $317(83.2 \%)$ & $516(85.30 \%)$ & 0.05 \\
\hline Dependence & $25(10.9 \%)$ & $64(16.8 \%)$ & $89(14.70 \%)$ & \\
\hline Physical Performance & & & & \\
\hline Good & $123(53.5 \%)$ & $122(32 \%)$ & $245(40.10 \%)$ & 0.001 \\
\hline Poor & $107(46.5 \%)$ & $259(68 \%)$ & $366(59.90 \%)$ & \\
\hline History of fall & & & \\
\hline No & $192(83.5 \%)$ & $303(79.5 \%)$ & $495(81 \%)$ & 0.228 \\
\hline Yes & $38(16.5 \%)$ & $78(10.7 \%)$ & $116(19 \%)$ & \\
\hline Frequency of fall & & & & \\
\hline 1 fall & $27(71.1 \%)$ & $51(65.4 \%))$ & $78(67.2 \%)$ & 0.528 \\
\hline 2 or more fall & $11(28.9 \%)$ & $27(34.6 \%$ & $38(32.8 \%)$ & \\
\hline
\end{tabular}

Table 2 Risk of falling for older adult living in Urban and Rural area 


\begin{tabular}{|c|c|c|c|c|}
\hline Risk Factor for fall & Urban & & Rural & \\
\hline Variables & Crude OR & $\begin{array}{l}\text { Adjusted OR } \\
\text { 95\% C.I. }\end{array}$ & Crude OR & $\begin{array}{l}\text { Adjusted OR95\% } \\
\text { C.I. }\end{array}$ \\
\hline \multicolumn{5}{|l|}{ Gender } \\
\hline Male & $\begin{array}{l}1.525(0.749- \\
3.106)\end{array}$ & $\begin{array}{l}0.289(0.095- \\
0.882)^{\star}\end{array}$ & $\begin{array}{l}1.349(0.762- \\
2.387)\end{array}$ & $\begin{array}{l}1.004 \\
1.849)\end{array}(0.545-$ \\
\hline Female (Ref) & 1 & & 1 & 1 \\
\hline \multicolumn{5}{|l|}{ Ages } \\
\hline 60-69 Years old & $\begin{array}{l}0.821(0.092- \\
7.363)\end{array}$ & $\begin{array}{l}1.213(0.116- \\
12.645)\end{array}$ & $\begin{array}{l}0.858(0.385- \\
1.916)\end{array}$ & $\begin{array}{l}0.917(0.385- \\
2.184)\end{array}$ \\
\hline $70-79$ years old & $\begin{array}{l}1.415(0.153- \\
12.058)\end{array}$ & $\begin{array}{l}2.385(0.223- \\
25.45)\end{array}$ & $\begin{array}{l}0.644(244- \\
1,702)\end{array}$ & $\begin{array}{l}0.659(0.241- \\
1.806)\end{array}$ \\
\hline $\begin{array}{l}80 \text { years old or } \\
\text { more (ref) }\end{array}$ & 1 & 1 & 1 & 1 \\
\hline \multicolumn{5}{|l|}{ Current Occupation } \\
\hline Actively working & $\begin{array}{l}0.835(0.318- \\
2.193)\end{array}$ & $\begin{array}{l}0.416(0.131- \\
1.322)\end{array}$ & $\begin{array}{l}0.950(0.577- \\
1.566)\end{array}$ & $\begin{array}{l}0.873(0.497- \\
1.533)\end{array}$ \\
\hline Not Working (ref) & 1 & 1 & 1 & 1 \\
\hline \multicolumn{5}{|l|}{ Visual Impairment } \\
\hline \multicolumn{5}{|l|}{ No (ref) } \\
\hline Yes & $\begin{array}{l}2.478(1.185- \\
0.183)^{\star}\end{array}$ & $\begin{array}{l}3.601(1.517- \\
8.544)^{\star \star}\end{array}$ & $\begin{array}{l}1.896(1.108- \\
3.244) *\end{array}$ & $\begin{array}{l}1.807(1.027- \\
0.179)^{\star}\end{array}$ \\
\hline \multicolumn{5}{|l|}{ Hearing Impairment } \\
\hline \multicolumn{5}{|l|}{ No (ref) } \\
\hline Yes & $\begin{array}{l}1.959(0.802- \\
4.787)\end{array}$ & $\begin{array}{l}1.538(0.554 \\
4.271)\end{array}$ & $\begin{array}{l}1.392(0.799- \\
2.425)\end{array}$ & $\begin{array}{l}1.214 \\
2.187)\end{array}$ \\
\hline \multicolumn{5}{|l|}{$\begin{array}{l}\text { Chronic Medical } \\
\text { Condition }\end{array}$} \\
\hline $\begin{array}{l}\text { No chronic illness } \\
\text { (ref) }\end{array}$ & 1 & & 1 & \\
\hline $\begin{array}{l}\text { With Chronic } \\
\text { illness }\end{array}$ & $\begin{array}{l}2.657(1.112- \\
6.347)^{\star}\end{array}$ & $\begin{array}{l}3.247(1.236- \\
8.533)^{\star \star}\end{array}$ & $\begin{array}{l}1.652(0.845- \\
3.231)\end{array}$ & $\begin{array}{l}1.516(0.761 \text { - } \\
3.019)\end{array}$ \\
\hline \multicolumn{5}{|l|}{$\begin{array}{l}\text { Physical } \\
\text { Performance }\end{array}$} \\
\hline Good & 1 & & 1 & \\
\hline
\end{tabular}




\begin{tabular}{|c|c|c|c|c|}
\hline Poor & $\begin{array}{l}2.329(0.524- \\
10.352)\end{array}$ & $\begin{array}{l}.545(0.166 \text { - } \\
1.788)\end{array}$ & $\begin{array}{l}.765(0.202- \\
2.897)\end{array}$ & $\begin{array}{l}.98(0.485 \text { - } \\
1.98)\end{array}$ \\
\hline \multicolumn{5}{|l|}{$\begin{array}{l}\text { The need of ADL } \\
\text { support }\end{array}$} \\
\hline $\begin{array}{l}\text { Independence } \\
\text { (ref) }\end{array}$ & 1 & 1 & 1 & 1 \\
\hline Dependence & $\begin{array}{l}.766(0.268- \\
2.191)\end{array}$ & $\begin{array}{l}1.022(0.468 \text { - } \\
2.231)\end{array}$ & $\begin{array}{l}1.012(0.519- \\
1.972)\end{array}$ & $\begin{array}{l}.792(0.458 \text { - } \\
1.369)\end{array}$ \\
\hline \multicolumn{5}{|c|}{ Living environment } \\
\hline Safe & 1 & 1 & 1 & 1 \\
\hline Unsafe & $\begin{array}{l}704(0.335- \\
1.480)\end{array}$ & $\begin{array}{l}.51(0.219- \\
1.192)\end{array}$ & $\begin{array}{l}3.636(1.276- \\
\left.0.357^{\star *}\right)\end{array}$ & $\begin{array}{l}3.358(1.137- \\
9.921)^{\star *}\end{array}$ \\
\hline
\end{tabular}

Note; $*$ $p \leq 0.01 * p \leq 0.05$ 